\title{
Designing an interactive learning application for ADHD children
}

\author{
Dian Kusumasari ${ }^{1}$, Danang Junaedi2, ${ }^{2, *}$, and Emil Robert Kaburuan ${ }^{3}$ \\ ${ }^{1}$ Telkom University, School of Computing, Informatics Department, Jl. Telkomunikasi Bandung, Indonesia \\ ${ }^{2}$ Telkom University, School of Computing, Information Technology Department, J1. Telkomunikasi Bandung, Indonesia \\ ${ }^{3}$ Bina Nusantara University, Information System Management, Jl. Kebon Jeruk Jakarta - Indonesia
}

\begin{abstract}
This research focused on ADHD children with problems such as lack of attention, hyperactive, and impulsive that affect their school academic skills. Educational disturbances found in children with ADHD at Elementary School are low interest in learning, weak memorizing, unenthusiastic with large text and lack of concentration. They have less interest in Social Science Subjects. There are some learning applications developed to help children learn social science. However, there is none focused on ADHD children. Thus, a study was conducted to determine the user interface model of interactive learning application of social science subjects in accordance with user experience in ADHD children by implementing the Children-Centered Design method. Then we analyzed the application usability level measured using USE Questionnaire. The usability testing of the prototype has resulted in average usability of $90.05 \%$, this shows the category of application is very good and can be used for children ADHD.
\end{abstract}

\section{Introduction}

Children with ADHD in Indonesia have two kinds of different characteristics, namely ADD and ADHD. In this study will discuss ADHD, which is a lack of attention, hyperactive, and impulsive. Symptoms that found in ADHD children are less concentration, hyperactive, easy to forget, impulsive (quickly acted suddenly following the mood), like audio or visible objects, easily bored, low memory [1]. When a child exhibits behavior related to ADHD symptoms, it is likely to find difficulties with academics (loss of attention and concentration, even distracted about the situation or objects around the learning environment) and relationships with playmates [2]. In general, the problem of education in children with ADHD at the elementary school level is low learning interest, weak in terms of memorization, not interested in subjects that contain lots of text (one of them is social science subjects), and low concentration that makes it difficult for children to focus when teachers explain the material in the classroom. Thus, ADHD children are difficult to learn when subject matter that requires long memorization that tends to be boring, so the lesson is less fun for the child [1].

Children and families live can be connected with digital cloud that growing rapidly by an application [3]. Teachers can provide an incentive to help children learn through computer media [4]. These ADHD kids are familiar with the smartphones they used to play. Electronic learning apps using mobile devices also known as mobile learning can be used as a media for learning [5]. They are very easy to adapt to the computer and smartphone operators. Often encountered in this ADHD child, likes mobile applications that with an attractive appearance regarding color and image [1]. So good design is important to be a visual appeal for children, helping groups with identical age goals identify with apps, as important support for content and usability [6].

Visual media given to children can make it easier to understand and remember the information provided. Therefore, it takes the visual media as a learning tool for children with ADHD. Interactive learning applications in children with ADHD is expected to facilitate in learning a material that contains a lot of text one of them Social Sciences, using applications on smartphones.

Child-Centered Design is used in this study to determine the child's needs according to age target. By using this method, the author will be easier in doing research and analysis for the needs of ADHD children. It can include parents and teachers or psychologists in the process of application design. Thus, a user interface model and user experience can be generated to test the child in measuring usability on the prototype. In designing, it is important regarding understanding and determining the usage context, defining user and organizational needs, providing prototype solutions, and evaluating designs against user needs [7]. USE Questionnaire that has many dimensions of usability as an important dependent variable for users [8] will be used to measure the usability levels generated on the prototype. USE Questionnaire is one measure of usability by dividing into three main parameters namely usefulness, satisfaction, and ease of use. This study aims to find out how the user interface model that has been designed by implementing Child-Centered would help in the interactive learning on Social Science.

\footnotetext{
* Corresponding author: danangjunaedi@telkomuniversity.ac.id
} 


\section{Literature review}

\subsection{Attention-Deficit Hyperactivity Disorder (ADHD) children attention-deficit I hyperactivity disorder}

(ADHD) is one of the most frequently diagnosed in behavioral disorders in childhood [9]. 3-5\% of children worldwide suffer from ADHD. Children with ADHD will have excessive anxiety, impulsivity, irritability [10]. The problems encountered by ADHD children usually causes difficulties in one or more of the living environment such as home, school, or social relationships. Regarding gadgets for children with ADHD, stating that the ADHD child has become accustomed to the use of gadgets which are not recommended in a period often at an early age will have a negative impact on the child's development [1].

\subsection{Child-centered design}

CCI is a scientific research which concerns about the phenomenon of interaction between children and computing and communication technology [11]. ChildCentered Design is the development of User-Centered Design where the users are children [12]. The process could be seen in Fig. 1 below:

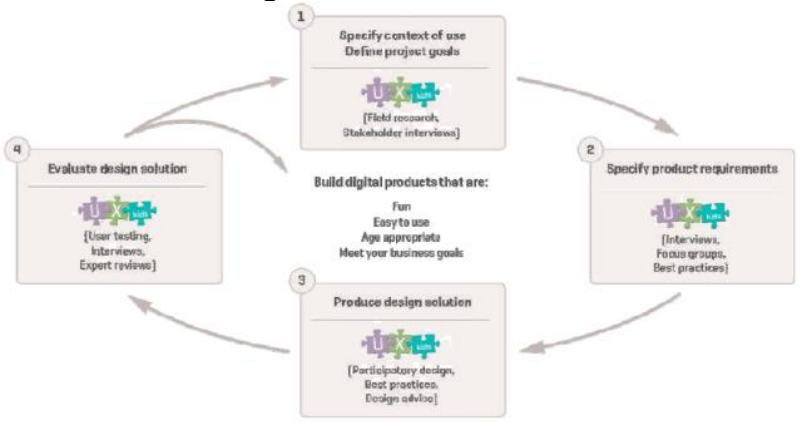

Fig. 1. Child-centered design [12].

\subsection{USE Questionnaire}

USE Questionnaire is used to evaluate user attitudes toward products using three dimensions: usefulness, satisfaction, and ease of use. The product user is asked to judge from the given statement, range from strongly disagreeing to strongly agreeing on 7 points Likert Scale [13]. After getting usability value, it can be interpreted by using SUS (The System Usability Scale) shown in Fig.2. SUS serves as a quantitative tool to find out how far the value of usability derived from applications that have been built [14].

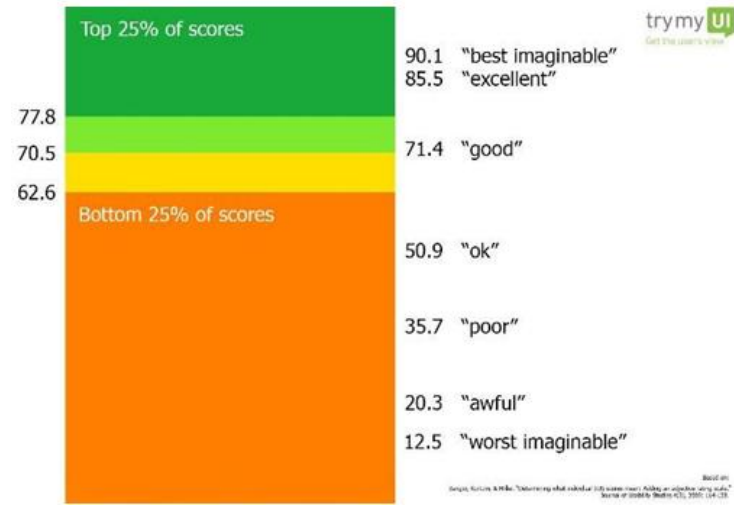

Fig. 2. The system usability scale [8].

\section{Design process}

Based on the steps in the CCD method, the design flows implemented to generate the user interface model are described as follows:

\subsection{User persona}

The researcher collected the user data from the children and created the user persona. The user persona is used to determine application requirements. Table 1 below is the user persona:

Table 1. User persona.

\begin{tabular}{|c|c|}
\hline Profile & $\begin{array}{l}\text { - Age range of 6-7 years } \\
\text { - Male and female } \\
\text { - Hyperactive } \\
\text { - Lack of concentration (easily distracted) in } \\
\text { doing an activity } \\
\text { - Impulsive (quick acting suddenly following } \\
\text { mood) } \\
\text { - Easily bored } \\
\text { - Low motivation regarding learning kindergarten } \\
\text { students }\end{array}$ \\
\hline Task & $\begin{array}{l}\text { - Learning Social Studies by reading books and } \\
\text { listening to teachers } \\
\text { - Learning only when there is a tutor } \\
\text { - Learning when close to exam }\end{array}$ \\
\hline Behaviour & $\begin{array}{l}\text { - Frequently watching videos on YouTube } \\
\text { - Excessive activity (active) } \\
\text { - Prefer lessons in arithmetic } \\
\text { - Love English lessons } \\
\text { - Likes challenging thing }\end{array}$ \\
\hline Social & $\begin{array}{l}\text { - Easy to adjust to new environments } \\
\text { - Doing learning activities at school and home } \\
\text { - Often makes a scene by disturbing or teasing } \\
\text { friends around }\end{array}$ \\
\hline $\begin{array}{l}\text { Expertise } \\
\text { application } \\
\text { software }\end{array}$ & $\begin{array}{l}\text { - Can be quiet when playing smartphone } \\
\text { - Can recognize the icon in the application } \\
\text { - Can operate smartphone without the help of } \\
\text { anyone (download to operate the application) } \\
\text { - Accustomed to playing games on smartphones } \\
\text { - The time needed to understand how the } \\
\text { application work only } 1-2 \text { times (if given } \\
\text { direction) }\end{array}$ \\
\hline Obstacles & $\begin{array}{l}\text { - It takes a long time to type or write a word / } \\
\text { sentence } \\
\text { - Easily get bored } \\
\text { - Hard to learn and read books } \\
\text { - Do not like lessons that need to memorize such } \\
\text { as social science }\end{array}$ \\
\hline
\end{tabular}




\subsection{User requirements}

After creating user persona, then there should be user requirement. Table 2 below the user requirement that has been defined.

Table 2. User requirements.

\begin{tabular}{|l|l|l|}
\hline Goals & Needs & Requirement \\
\hline $\begin{array}{l}\text { Learning social } \\
\text { science as well } \\
\text { as playing with } \\
\text { smartphone } \\
\text { media }\end{array}$ & $\begin{array}{l}\text { Fill in the game } \\
\text { with material live } \\
\text { in harmony in as } \\
\text { seen in grade 1 } \\
\text { social science book }\end{array}$ & $\begin{array}{l}\text { App features have } \\
\text { learning content that } \\
\text { meets the needs of } \\
\text { users }\end{array}$ \\
\hline $\begin{array}{l}\text { Not easily } \\
\text { bored }\end{array}$ & $\begin{array}{l}\text { The design of } \\
\text { application is } \\
\text { colourful and } \\
\text { includes pictures }\end{array}$ & $\begin{array}{l}\text { Application features } \\
\text { contains images and } \\
\text { backgrounds that } \\
\text { appeal to the user }\end{array}$ \\
\hline $\begin{array}{l}\text { Challenged to } \\
\text { learn social } \\
\text { science with } \\
\text { apps }\end{array}$ & $\begin{array}{l}\text { The game } \\
\text { presented a variety } \\
\text { of questions the } \\
\text { longer it has more } \\
\text { complex degree of } \\
\text { difficulty }\end{array}$ & $\begin{array}{l}\text { Game features are } \\
\text { presented in the } \\
\text { form of many } \\
\text { questions that can } \\
\text { provide appropriate } \\
\text { illustrations of each } \\
\text { question and provide } \\
\text { different model } \\
\text { questions according } \\
\text { to the difficulty } \\
\text { level of the question } \\
\text { (such as a sentence } \\
\text { question and an } \\
\text { image choice }\end{array}$ \\
\hline $\begin{array}{l}\text { Earn } \\
\text { appreciation in } \\
\text { the form of } \\
\text { reward } \\
\text { completing the } \\
\text { game }\end{array}$ & $\begin{array}{l}\text { Accumulation } \\
\text { correct and wrong } \\
\text { answers }\end{array}$ & $\begin{array}{l}\text { The feature displays } \\
\text { the reward results } \\
\text { that can be collected } \\
\text { from the correct } \\
\text { answers on each } \\
\text { game }\end{array}$ \\
\hline
\end{tabular}

\subsection{Design and implementation}

The design results in the previous stage (wireframe [13] and mock-up), then implemented into prototype applications [14]. Fig.3 until Fig. 10 below are the screenshot of the application.

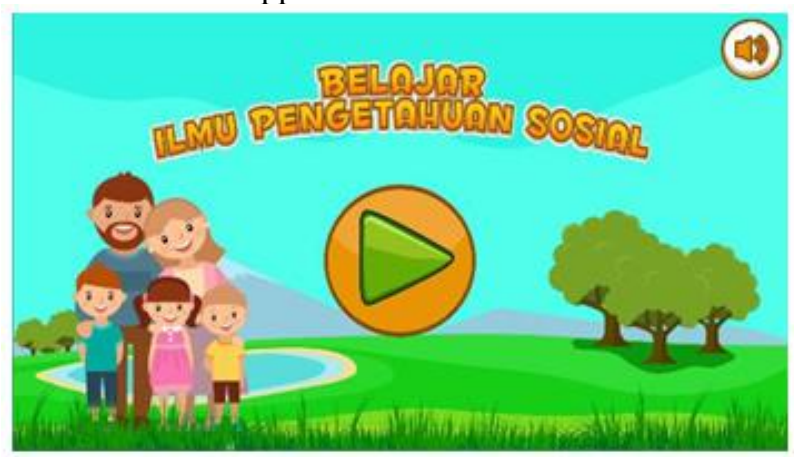

Fig. 3. Home page.

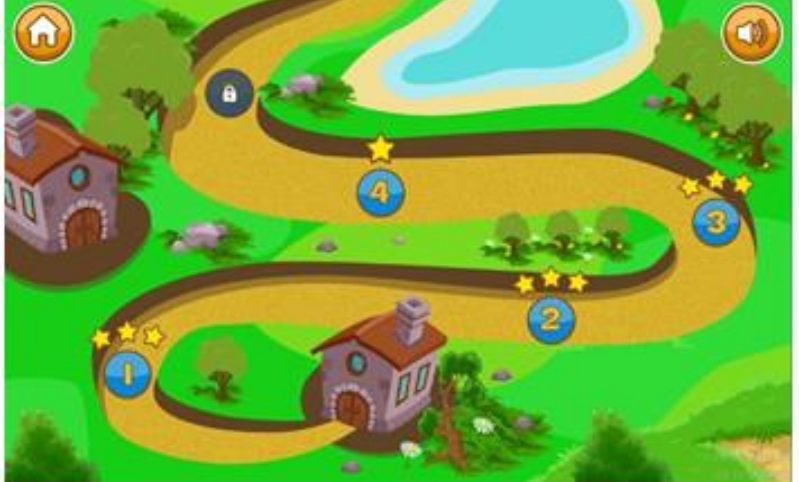

Fig. 4. Game level page.

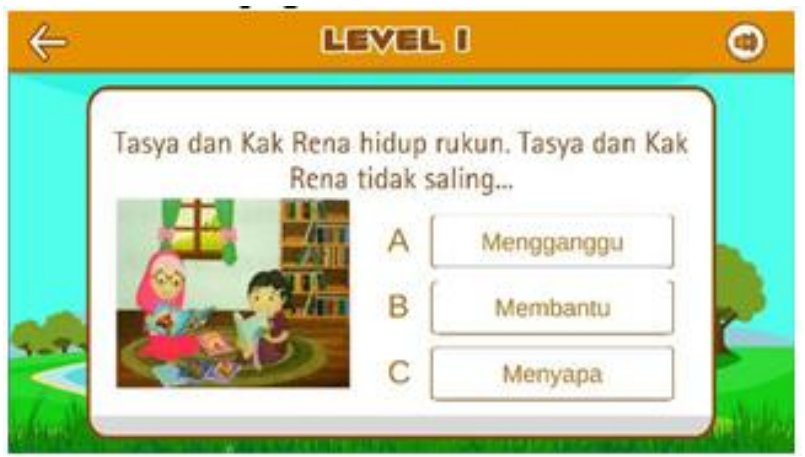

Fig. 5. Sample question in level 1.

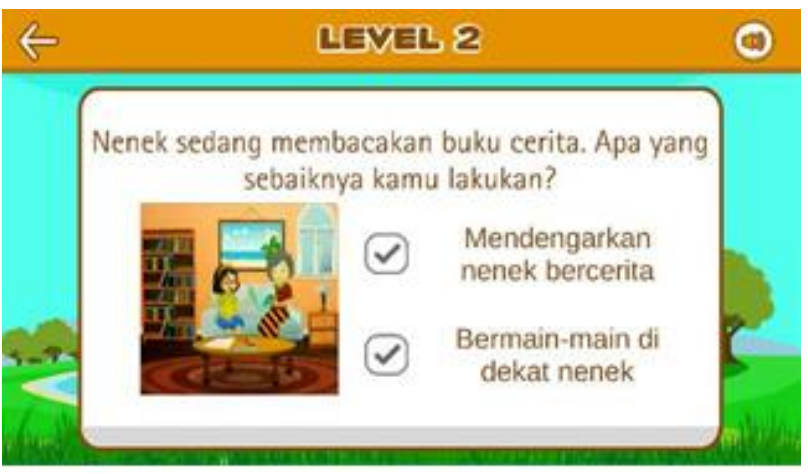

Fig. 6. Sample question in level 2.

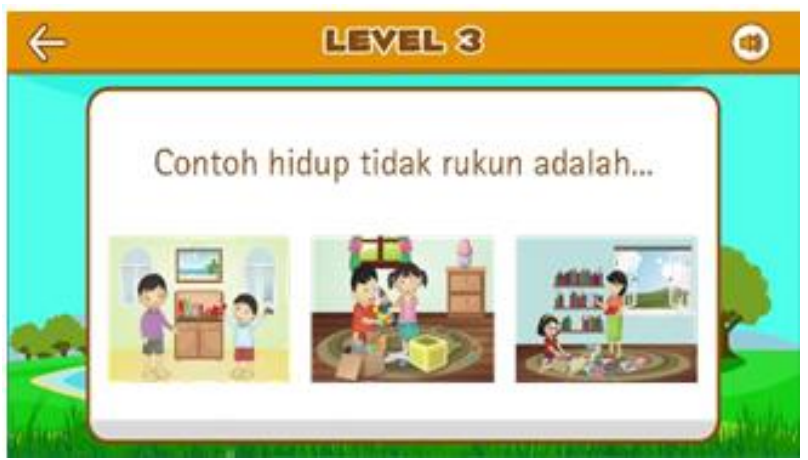

Fig. 7. Sample question in level 3. 


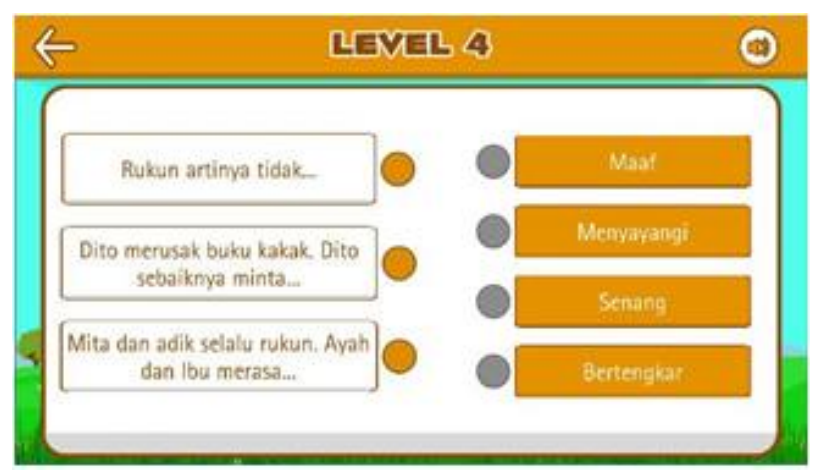

Fig. 8. Sample question in level 4.

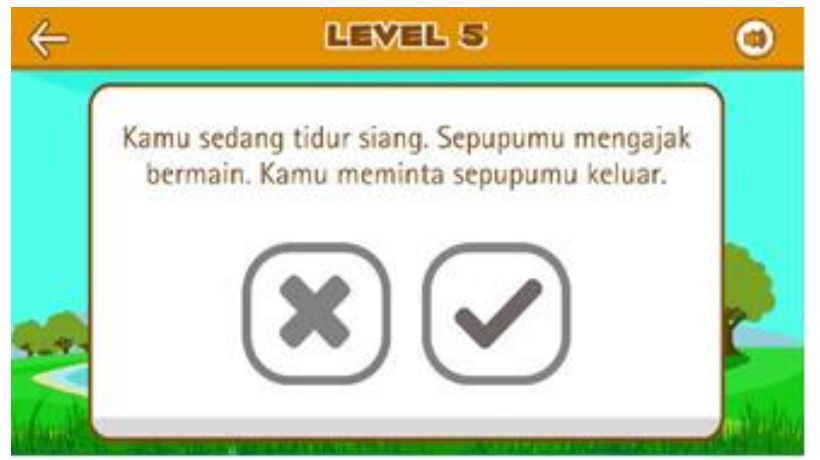

Fig. 9. Sample question in level 5.

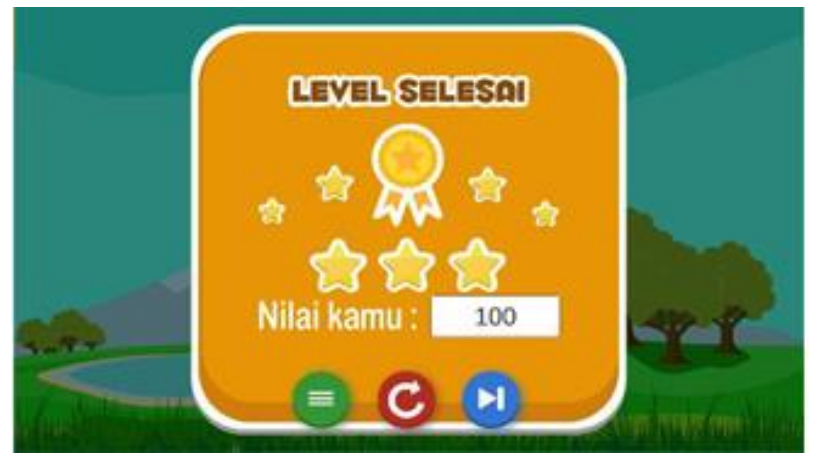

Fig. 10. Pop up reward.

The result of usability testing using USE Questionnaire for each factor, SUS results are presented below:

Table 3. USE questionnaire result.

\begin{tabular}{|l|l|l|}
\hline Factor & Percentage & Category \\
\hline Usefulness & $89.71 \%$ & Excellent \\
\hline Satisfaction & $87.43 \%$ & Excellent \\
\hline Easy to use & $93.57 \%$ & Best imaginable \\
\hline Easy of learning & $89.52 \%$ & Excellent \\
\hline Average & $90.05 \%$ & Excellent \\
\hline
\end{tabular}

Presenting data analysis results obtained from the percentage value of each factor in USE Questionnaire. Here's a thorough explanation of the test results as well as data processing:
- The average percentage value gained $90.05 \%$, in SUS (The System Usability Scale) shows usability value obtained in the excellent category [15].

- The lowest result is $87.43 \%$ of the satisfaction factor. The possible causes would be the design approach to the needs of ADHD children are mostly recommended by psychologists, not directly from children. Playing game apps will have a negative impact on the child, for example, if the child addicted to playing the game apps, then the child would become individual, difficult to control emotionally, and child motor sensor is disturbed.

\section{Conclusion}

From the analysis and implementation of child-centered design method on the research of user interface model design on interactive learning application of social science that fits the user experience in ADHD children as follows:

- User experience indicates that ADHD child does not like learning by having more reading and listening in a material, they prefer learning through exercise questions and direct questions when something could not understand to the companion. They like challenges that make the child not easily bored and challenged in doing some learning activity.

- The user interface model designed in the form of a variety of questions and presented with a level difficulty to challenge the ADHD children so they would not get easily bored. This learning method can help children in learning IPS that they are initially boring to be fun. This in-app material only takes one difficult chapter for the ADHD child is a harmonious life chapter based on chapter material selection by an ADHD child therapist.

- The various model question is presented from level 1 to level 5, where each level presents three questions. Model questions at level 1 to level 5 were obtained based on interviews with ADHD child therapists.

- There is a reward for each level passed. The reward aims to give appreciation and motivation to ADHD children to get 100 scores (perfect), when they can earn 100, then it will continue the next level. It aims to provide challenges, as well as for ADHD children to understand the material through the answer given.

- To know the true or false answer given by the child, there is added feedback in the form of audio. If the child answers incorrectly the application gives a response of "o-oh" audio that indicates that the selected answer is wrong and vice versa if audio "succeed" indicating that the selected answer is correct.

- On usability testing with USE Questionnaire on prototype results that have been built to obtain an average result of usability value of $90.05 \%$, It goes to the "excellent" category which shows that the application has a very good usability, it can be interpreted that the application has been designed meet the needs of the child as a learning application. 
But this study has not been tested for the impact of the use of applications in the social science learning process in ADHD children that aims to determine whether or not increased understanding of children after using the application.

\section{Recommendation}

Based on the results of tests, that the application has very good usability score, for it is expected the next researcher focus to see a further impact on the level of understanding, mastery, and achievement results of ADHD children on living material in the Social Sciences subjects. Thus, it is necessary to pre-test and post-test. Pre-test as an activity to test the level of knowledge of the child on the material in the form of questions before using the application, then given the application in each learning process. Researchers give a minimum distance of 15 days (maximum 30 days) between pre-test and post-test. After the child uses the application, then do a post-test in the form of questions to evaluate the child's understanding of the information obtained on the application. Calculate the percentage value of the acquisition of child knowledge improvement of ADHD children after pre-test and post-test. If it does not get an increase in the percentage obtained, then it is necessary to realize the design improvements and to test on the second iteration.

\section{References}

1. D. Kumaladewi, A. D. Istiarini, Konsultasi Mengenai anak ABK dengan Attention-Deficit Hyperactivity Disorder(2016)

2. A. Mahabbati, Pendidikan Inklusif untuk Anak dengan Gangguan Emosi dan Perilaku (Tunalaras), Jurnal Pendidikan Khusus 7, 2, 52-63 (2010)

3. Hirsh-Pasek, Putting Education in "Educational" Apps Lessons from the Science of Learning, Psychological Science in the Public Interest 16, 1, 3-34 (2015)

4. J. P. Hourcade, Interaction Design and Children, Human-Computer Interaction 1, 4, 277-392 (2007)

5. A. Kukulska-Hulme, J. Traxler, Mobile teaching and learning," in Mobile Learning: A Handbook for Educators and Trainers (London: Routledge, 2005)

6. UXLady, Introduction to User Personas, Retrieved from http://www.ux-lady.com: http://www.uxlady.com/introduction-to-user-personas/ (2013)

7. M. K. Sabariah, V. Effendy, D. Junaedi, Interaksi Manusia dan Komputer (Bandung: Diandra Kreatif, 2015)

8. A. M. Lund, Measuring usability with the USE questionnaire, Retrieved from Measuring Usability with the USE Questionnaire. STC Usability SIG Newsletter, 8:2.

http://garyperlman.com/quest/quest.cgi?form=USE/ . (2016)
9. M. Fowler, Attention-Deficit/ Hyperactivity Disorder, National Dissemination Center for Children with Disabilities 24 (2004)

10. Understanding the Child-Centered Design (CCD) process, Retrieved from UX Kids: http://uxkids.com/ccd.html (2017)

11. P. Markopoulus, J. Read, International Journal of Child-Computer Interaction, ELESEVIER, 1-5 (2012)

12. S. Idler, Child-Centered Design is User-Centeres Design, But Then Different, Retrieved from UXKids: http://uxkids.com/blog/child-centereddesign-is-user-centered-design-but-thendifferent/.(2013, August 16)

13. N. J. Garrett, Conceptual Models; Wireframes, (Berkeley, 2011)

14. User Experience Professionals Association. Prototyping Methods. Retrieved from Usability Book: http://www.usabilitybok.org/prototypingmethods/ (2010)

15. Trymy, UI SUS: The System Usability Scale. Retrieved from http://www.trymyui.com/sussystem-usability-scale/ (2017) 